\title{
Ischemia-modified albumin and other inflammatory markers in the diagnosis of appendicitis in children
}

\author{
Selçuk Nazik, M.D., ${ }^{1}$ Veli Avci, M.D., ${ }^{2}$ Zeynep Küskü Kiraz, M.D. ${ }^{3}$ \\ ${ }^{1}$ Department of Infectious Diseases and Clinical Microbiology, Bingöl Maternity and Children's Hospital, Bingöl-Turkey \\ 2Department of Pediatric Surgery, Bingöl Maternity and Children's Hospital, Bingöl-Turkey \\ ${ }^{3}$ Department of Biochemistry, Osmangazi University Faculty of Medicine, Eskişehir-Turkey
}

\begin{abstract}
BACKGROUND: The aim of the present study was to determine relationship of ischemia-modified albumin (IMA) level, C-reactive protein (CRP) level, erythrocyte sedimentation rate (ESR), white blood cell (WBC) count, neutrophil-to-lymphocyte ratio (NLR), platelet-to-lymphocyte ratio (PLR), and mean platelet volume (MPV) to appendicitis in children.
\end{abstract}

METHODS: Study included total of 63 patients who presented at hospital between May 2015 and November 20I5. Of these, 30 were cases of appendicitis, and 33 were healthy control subjects. The groups were statistically similar in age and gender.

RESULTS: Receiver operating characteristic curve was evaluated for IMA, CRP, ESR, WBC, MPV, NLR, and PLR values in patients with appendicitis, and IMA was determined to have highest area under the curve value (0.99I), followed by NLR (0.946), CRP (0.808), PLR (0.779), ESR (0.767), WBC (0.749), and MPV (0.583).

CONCLUSION: Use of NLR, PLR, IMA, and ESR values may be helpful in diagnosis of appendicitis, in addition to WBC and CRP values, lower right quadrant abdominal pain, and ultrasonography signs commonly used.

Keywords: Appendicitis; inflammatory markers; ischemia-modified albumin.

\section{INTRODUCTION}

Appendicitis is a common cause of emergent surgical intervention in children. Obstruction of the appendix lumen is the most important factor in the etiology of appendicitis. [1] Blockage, for example with mucus, leads to swelling and increased pressure within the lumen and the walls of the appendix. This pressure results in thrombosis and occlusion of the small vessels, and stasis of lymphatic flow. As occlusion of blood vessels progresses, the appendix becomes ischemic, and then necrotic. ${ }^{[2,3]}$ Lifetime incidence of appendicitis is $7 \%$. Rate of mortality is less than $1 \%$ in the general population; however, this rate increases to as much as $50 \%$ in advanced

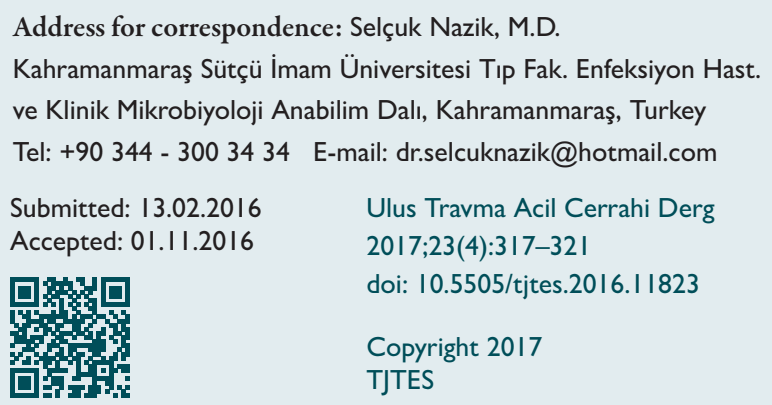

age groups. Diagnosis of appendicitis has been made based on lower right quadrant abdominal pain and increased number of leukocytes, but sensitivity of these signs is low. Measures such as Alvarado score, neutrophil-to-lymphocyte ratio (NLR), number of white blood cells (WBC), and C-reactive protein (CRP) level have also been used in the diagnosis of appendicitis. Nevertheless, rate of false positivity in diagnosis is still approximately 15\%.4 ${ }^{[4-6]}$ Level of biomarker ischemiamodified albumin (IMA) increases secondary to ischemia of the myocardium and skeletal muscle, and can be measured using albumin-cobalt binding test. ${ }^{[7,8]}$ Complete blood count $(\mathrm{CBC})$ is an easily available and inexpensive test. WBC, neutrophil and lymphocyte counts, and value of mean platelet volume (MPV) are evaluated in $C B C$ test. These values and ratios, such as NLR and platelet-to-lymphocyte ratio (PLR) are commonly used as inflammatory markers.

The aim of the present study was to determine relationship between appendicitis and markers of CRP, erythrocyte sedimentation rate (ESR), WBC, NLR, PLR, MPV, and IMA.

\section{MATERIALS AND METHODS}

The study included a total of 63 patients who presented at 
hospital between May 2015 and November 2015. Of these, 30 were cases of appendicitis in patients below 18 years of age, and 33 were healthy control subjects. Groups were similar in age and gender distribution. The ethics committee of the Bingöl General Secretariat of the Association of Public Hospitals approved the study. Families of the participants were informed about the study, and provided written consent. Appendicitis cases were evaluated in 2 groups: acute appendicitis (AA) and perforated appendicitis (PA). Age, gender, and laboratory analysis values were recorded for patient and control groups. CBC, CRP, and ESR were analyzed using Beckman Coulter LH 750, Beckman Coulter Immage $\mathbf{8 0 0}$ (Beckman Coulter, Inc., Brea, CA, USA) and Linear analyzer (Linear Chemicals, S.L., Montgat, Spain), according to the guidelines of the manufacturers.

\section{Analysis of Ischemia-Modified Albumin}

Serum IMA values were analyzed using principle of albumincobalt binding defined by Bar-Or et al. using Mindray BS-2000 auto analyzer (Mindray Medical International Ltd., Shenzhen, China). ${ }^{[7]}$ According to this method, $100 \mu \mathrm{L}$ of cobalt dichloride reagent was added to $35 \mu \mathrm{L}$ of serum and incubated for 5 minutes. During this incubation period, cobalt [Co(II)] binds to the $\mathrm{N}$-terminal of unmodified albumin. When $50 \mu \mathrm{L}$ of dithiothreitol (DTT) reagent is added, DTT combines with unbound $\mathrm{Co}(\mathrm{II})$, and results in color development. Color change of the sample was evaluated at $470 \mathrm{~nm}$, and values were measured in absorbance units ( $\mathrm{AbsU}$ ).

\section{Statistical Analysis}

Study data were evaluated using SPSS Statistics for Windows, Version 17.0 statistical software (SPSS Inc., Chicago, IL, USA). Continuous variables were expressed as mean $\pm S D$, and categorical variables were expressed in numbers and percent values. Student's t-test was used to compare continuous variables between independent groups. For categorical variables, chi-square test was used to compare independent groups. Receiver operating characteristic (ROC) curve was used to evaluate the power of markers to predict appendicitis. The following major criteria were used in ROC analysis to define best predicting test: value of sensitivity $100 \%$, value of false positivity as zero ( 1 -specificity $=0)$, area under the curve (AUC) of I, and diagnostic value of AUC of $p<0.05$. Youden's index was used to determine cut-off value; this index reflects maximum value of sum of sensitivity and specificity, overlapping with nearest point to upper left angle in ROC graph. In evaluating accuracy of diagnostic test, sensitivity and specificity were calculated at $95 \%$ confidence interval $(\mathrm{Cl})$. $\mathrm{P}$ value $<0.05$ was accepted as statistically significant.

\section{RESULTS}

Study included total of 63 cases. Of these, 30 (47.6\%) were cases with appendicitis and 33 (52.4\%) were controls. Group with appendicitis included 18 males (60\%) and 12 females (40\%), and control group included 23 males (69.7\%) and $10 \mathrm{fe-}$ males $(30.3 \%)$. There was no statistically significant difference between groups in distribution of gender $(p=0.420)$. Mean age of patients with appendicitis and controls was II9.2 \pm 27.4 months and $105.6 \pm 30.8$ months, respectively. Difference in age was not statistically significant between groups $(p=0.07)$. Among cases with appendicitis, 27 (90\%) had AA, and 3 (10\%) had PA. Of cases with AA, 12 (44.4\%) were younger than 120 months of age, and I5 (55.6\%) were 120 months of age or older. Of the cases with PA, I (33.3\%) was younger than 120 months of age, and 2 (66.7\%) were 120 months of age or older.

Values of CRP, ESR, WBC, NLR, and IMA in appendicitis and control groups are presented in Table I.

Calculations for cut-off, sensitivity, specificity, AUC, $95 \% \mathrm{CI}$, and $p$ value regarding power of ESR, CRP, WBC, MPV, NLR, PLR, and IMA to predict cases with appendicitis and results are presented in Table 2.

Table I. C-reactive protein, erythrocyte sedimentation rate, white blood cell, neutrophil lymphocyte ratio, and ischemia-modified albumin values in appendicitis and control groups

\begin{tabular}{|c|c|c|c|}
\hline & Appendicitis $(n=30)$ & Control $(n=33)$ & *p \\
\hline & Mean \pm SD & Mean \pm SD & \\
\hline Erythrocyte sedimentation rate $(\mathrm{mm} / \mathrm{h})$ & $25.90 \pm 17.0$ & $14.84 \pm 8.0$ & 0.002 \\
\hline C-reactive protein (mg/dL) & $29.63 \pm 41.3$ & $7.45 \pm 9.2$ & 0.007 \\
\hline White blood cell $\left(10^{3} / \mu \mathrm{L}\right)$ & $12.12 \pm 4.8$ & $7.73 \pm 2.1$ & 0.000 \\
\hline Mean platelet volume $(\mathrm{fL})$ & $8.23 \pm 0.8$ & $8.08 \pm 0.9$ & 0.501 \\
\hline Neutrophil lymphocyte ratio & $6.06 \pm 4.1$ & $1.24 \pm 0.8$ & 0.000 \\
\hline Platelet lymphocyte ratio & $164.23 \pm 77.3$ & $103.42 \pm 34.6$ & 0.000 \\
\hline Ischemia-modified albumin (AbsU) & $0.56 \pm 0.1$ & $0.33 \pm 0.1$ & 0.000 \\
\hline
\end{tabular}

"Groups were compared using Student's t-test. SD: Standard deviation. 
Table 2. Cut-off, sensitivity, specificity, area under curve, $95 \%$ confidence interval, and $p$ values regarding power of ESR, CRP, WBC, MPV, NLR, PLR, and IMA to predict appendicitis

\begin{tabular}{|c|c|c|c|c|c|c|}
\hline & Cut-off & Sensitivity \% & Specificity \% & Area under curve & $95 \% \mathrm{Cl}$ & "p \\
\hline $\operatorname{ESR}(\mathrm{mm} / \mathrm{h})$ & 17 & 76.7 & 75.8 & 0.767 & $64.2-89.1$ & 0.000 \\
\hline CRP (mg/dL) & 5.2 & 73.3 & 75.8 & 0.808 & $69.2-92.4$ & 0.000 \\
\hline WBC $\left(10^{3} / \mu \mathrm{L}\right)$ & 8.87 & 70 & 69.7 & 0.749 & $62.1-87.8$ & 0.001 \\
\hline$M P V(f L)$ & 8.15 & 53.3 & 60.6 & 0.583 & 44. I-72.6 & 0.256 \\
\hline NLR & 1.77 & 76.7 & 78.8 & 0.946 & $89.8-99.5$ & 0.000 \\
\hline PLR & 119.64 & 66.7 & 66.7 & 0.779 & $66.7-89.1$ & 0.000 \\
\hline IMA (AbsU) & 0.445 & 96.7 & 99.7 & 0.991 & $97.6-100$ & 0.000 \\
\hline
\end{tabular}

"Values in groups were calculated using receiver operating characteristic curve. Cl: Confidence interval; ESR: Erythrocyte sedimentation rate; CRP: C-reactive protein; WBC: White blood cell; MPV: Mean platelet volume; NLR: Neutrophil lymphocyte ratio; PLR: Platelet lymphocyte ratio.

\section{DISCUSSION}

Appendicitis is one of the most common causes of emergent surgical intervention in children. Clinical presentation (pain in the lower right abdomen, defense, and rebound), fever, high WBC count and CRP level, and ultrasonography (USG) signs are used in diagnosis of the disease. ${ }^{[9]}$ Patients with PA were screened in a study conducted by Gürleyik, and of the total, $69.7 \%$ were male and $30.3 \%$ were female. Among children, $70.9 \%$ of the patients were male and $29.1 \%$ were female. ${ }^{[10]}$ Yıldız et al. investigated risk factors in appendicitis in children and reported that $66.3 \%$ of patients with appendicitis were male. ${ }^{\left[{ }^{1 I}\right]}$ In the present study, most of the appendicitis patients were male, which was in accordance with the results in the literature.

Inflammatory markers have frequently been studied as indicators of appendicitis. Of these, CRP is most investigated marker. Albu et al. evaluated level of CRP in cases of AA and reported that sensitivity and specificity were $100 \%$ and $84.6 \%$, respectively, when cut-off value was $2.5 \mathrm{mg} / \mathrm{dL}^{\left[{ }^{12]}\right.} \mathrm{In}$ study performed by Mengücük et al., CRP level of patients with pathological diagnosis of appendicitis (focal, suppurative, or perforated) was statistically significantly higher when compared with cases that did not have pathological diagnosis of appendicitis. ${ }^{[13]}$ In another study conducted by Sack et al., CRP level of group with PA and group with abdominal pain who did not undergo surgery was compared. They found that CRP was significantly higher in group with PA $(p<0.001) .{ }^{[14]}$ In the same study, ESR level was also higher in group with appendicitis. In the current study, CRP and ESR values were also statistically significantly higher in patients with appendicitis, compared with control subjects.

Bozkurt et al. investigated WBC values in cases of appendicitis in preoperative period, and group with appendicitis had WBC level statistically significantly higher than that of control group $(p=0.001) .{ }^{[15]}$ Panagiotopoulou et al. found values of WBC $(p<0.000 I)$ and CRP $(p<0.000 I)$ were significantly higher in patients with AA compared with normal group. In another study, WBC value was statistically significantly higher in group of children with PA $(p<0.002)$ or suppurative appendicitis $(p<0.001)$, compared with group with abdominal pain who did not require surgery. However, when WBC of group with early appendicitis (mucosal ulceration and focal appendicitis) was compared that of group with abdominal pain who did not require surgery, no statistically significant difference was found $(p>0.05) .{ }^{[14]}$ In the present study, results were similar to those reported in the literature.

In study conducted by Kahramanca et al. to investigate NLR value in patients who underwent appendectomy, study groups comprised cases diagnosed as appendicitis histopathologically and those not diagnosed as appendicitis. ${ }^{[5]}$ In that study, NLR value in groups with and without appendicitis was 8. $10 \pm 7.0$ and $5.89 \pm 5.2$, respectively; this difference between groups was statistically significant $(p<0.001)$. The following values were determined in evaluation of ROC curve drawn to reveal power of NLR to predict cases with appendicitis: cutoff: 4.68; AUC: 0.639 ( $p<0.001$ ); sensitivity 65.3\%; specificity 84.6\%; and $95 \% \mathrm{Cl}, 59.1-68.7$. In another study performed by Jung et al., NLR value was compared between PA and non-PA groups, and it was determined that NLR value was statistically significantly higher in PA group $(p<0.001)$. AUC value of NLR was $0.755(95 \% \mathrm{Cl}, 0.660-0.834)$, cut-off value was 5.6, sensitivity was $78.0 \%$, and specificity was $65.9 \% .{ }^{[16]}$ In the current study, NLR value in group with appendicitis was statistically significantly higher than in control group, which was in accordance with results seen in the literature.

We did not find a study that evaluated relationship between appendicitis and PLR value in search of the literature. Thus, our results in this regard may be considered the first. In the current study, PLR value was statistically significantly higher in appendicitis cases, compared with control group $(p=0.000)$.

MPV indicates size and activity of platelets, and is used as an indicator of platelet dysfunction. Increased MPV value is relat- 
ed to thrombotic diseases and endothelial function disorders. [17] Controversial results have been obtained in studies investigating the importance of MPV in patients with appendicitis. Yardımcı et al. reported value of MPV in cases of appendicitis and control subjects of $9.3 \pm 8 \mathrm{fL}$ and $8.5 \pm 0.9 \mathrm{fL}$, respectively $(p=0.0005)$; the authors claimed that MPV value may be helpful in clinical determination of severity of AA. ${ }^{[18]}$ In another study performed by Sevinç et al., MPV value was statistically significantly lower in cases of appendicitis $(8.2 \pm 1.2 \mathrm{fL}) \mathrm{com}$ pared to normal appendix $(8.3 \pm \mathrm{I} . \mathrm{I} \mathrm{fL} ; \mathrm{p}=0.00 \mathrm{I})$. In addition, MPV was significantly lower in patients with complicated appendicitis $(p=0.001) .{ }^{[19]}$ Furthermore, Bozkurt et al. did not determine statistically significant difference between MPV value in cases of appendicitis and control group $(p=0.478)$. ${ }^{[15]}$ In our study, we found no relationship between MPV value and appendicitis, similar to result reported by Bozkurt et al.

Free radicals formed by tissue damage cause IMA to increase within minutes and it remains high for 6 to 12 hours before returning to normal value. Free radical damage that occurs in AA increases IMA value and helps in diagnosis of appendicitis. $^{[4,20-22]}$ Dumlu et al. investigated markers of oxidative stress in appendicitis cases in study that included 65 patients who underwent appendectomy and 30 control subjects. Two groups were evaluated regarding IMA level, since it increases in state of ischemia, and value in preoperative cases of appendicitis and controls was 0.64 $\pm 0.09 \mathrm{Abs} U$ and $0.3 \mathrm{I} \pm 0.09$ $\mathrm{AbsU}$, respectively. Value in group with appendicitis was statistically significantly higher when compared with control group $(p<0.00 I) .{ }^{[23]}$ In the current study, IMA value was also statistically significantly higher in patients with appendicitis; IMA was found to be better parameter in prediction of cases with appendicitis than other inflammatory markers.

Appendicitis is one of the most common reasons for emergent surgical intervention in children. Early diagnosis decreases rate of mortality and morbidity in cases of appendicitis, and is therefore extremely important. We conclude that use of NLR, PLR, IMA, and ESR values in diagnosis would be helpful, in addition to WBC and CRP values, lower right quadrant abdominal pain, and USG signs commonly used in diagnosis of appendicitis.

\section{Conflict of interest: None declared.}

\section{REFERENCES}

1. Engin O, Calik S, Calik B, Yildirim M, Coskun G. Parasitic appendicitis from past to present in Turkey. Iran J Parasitol 2010;5:57-63.

2. Danny OJ. Acute Appendicitis and Peritonitis. In: Dennis LK, Stephen LH, Jameson JL, Dan LL, Joseph L, Anthony SF, editors. Harrison's. 19th ed. New-York: McGraw-Hill; 2015. p. 1985-89.

3. Kadim AAM. Surgical and clinical review of acute appendicitis. International Journal of Multidisciplinary and Current Research 2016;4:280-7.

4. Kadıoğlu H, Kaptanoğlu L. The use of ischemia modified albumin in emergency surgery. J Kartal TR 2012;23:106-9. [CrossRef]
5. Kahramanca S, Ozgehan G, Seker D, Gökce EI, Seker G, Tunç G, et al. Neutrophil-to-lymphocyte ratio as a predictor of acute appendicitis. Ulus Travma Acil Cerrahi Derg 2014;20:19-22. [CrossRef]

6. Panagiotopoulou IG, Parashar D, Lin R, Antonowicz S, Wells AD, Bajwa FM, et al. The diagnostic value of white cell count, $C$-reactive protein and bilirubin in acute appendicitis and its complications. Ann R Coll Surg Engl 2013;95:215-21. [CrossRef]

7. Bar-Or D, Lau E, Winkler JV. A novel assay for cobalt-albumin binding and its potential as a marker for myocardial ischemia-a preliminary report. J Emerg Med 2000;19:311-5. [CrossRef]

8. Bhagavan NV, Lai EM, Rios PA, Yang J, Ortega-Lopez AM, Shinoda H, et al. Evaluation of human serum albumin cobalt binding assay for the assessment of myocardial ischemia and myocardial infarction. Clin Chem 2003:49:581-5. [CrossRef]

9. Chan L, Shin LK, Pai RK, Jeffrey RB. Pathologic continuum of acute appendicitis: sonographic findings and clinical management implications. Ultrasound Q 2011;27:71-9. [CrossRef]

10. Gürleyik G. Age and sex-specific changes in patients with perforated appendıcıtıs. Ulusal Cerrahi Dergisi 2001;17:111-6.

11. Yıldız T, Bozdağ Z, Erkorkmaz U, Emre A, Turgut T, Ilçe Z. Analysis of risk factors for the development of pediatric appendicitis. Ulus Travma Acil Cerrahi Derg 2013;19:554-8. [CrossRef]

12. Albu E, Miller BM, Choi Y, Lakhanpal S, Murthy RN, Gerst PH. Diagnostic value of C-reactive protein in acute appendicitis. Dis Colon Rectum 1994;37:49-51. [CrossRef]

13. Mengücük ME, Ayten R, Bülbüller N, Gödekmerdan A, Başbuğ M, Mungan İ. Role of Creactive Protein, Procalsitonin and Neopterin in the Diagnosis of Acute Appendicitis. Firat Tip Dergisi 2010;15:40-3.

14. Sack U, Biereder B, Elouahidi T, Bauer K, Keller T, Tröbs RB. Diagnostic value of blood inflammatory markers for detection of acute appendicitis in children. BMC Surg 2006;6:15. [CrossRef]

15. Bozkurt S, Köse A, Erdogan S, Bozali GI, Ayrik C, Arpaci RB, et al. MPV and other inflammatory markers in diagnosing acute appendicitis. J Pak Med Assoc 2015;65:637-41.

16. Jung SK, Rhee DY, Lee WJ, Woo SH, Seol SH, Kim DH, et al. Neutrophil-to-lymphocyte count ratio is associated with perforated appendicitis in elderly patients of emergency department. Aging Clin Exp Res 2016.

17. Vagdatli E, Gounari E, Lazaridou E, Katsibourlia E, Tsikopoulou F, Labrianou I. Platelet distribution width: a simple, practical and specific marker of activation of coagulation. Hippokratia 2010;14:28-32.

18. Yardımcı S, Uğurlu MÜ, Coşkun M, Attaallah W, Yeğen ŞC. Nötrofillenfosit oranı ve ortalama trombosit hacminin akut apandisitin şiddetini belirlemedeki rolü. Ulus Travma Acil Cerrahi Derg 2016;22:163-8.

19. Sevinç MM, Kınacı E, Çakar E, Bayrak S, Özakay A, Aren A, et al. Diagnostic value of basic laboratory parameters for simple and perforated acute appendicitis: an analysis of 3392 cases. Ulus Travma Acil Cerrahi Derg 2016;22:155-62.

20. Søreide K. The role of high-mobility group box-1 (HMGB-1) in the management of suspected acute appendicitis: useful diagnostic biomarker or just another blind alley? Scand J Trauma Resusc Emerg Med 2011;19:28.

21. Kalan M, Talbot D, Cunliffe WJ, Rich AJ. Evaluation of the modified Alvarado score in the diagnosis of acute appendicitis: a prospective study. Ann R Coll Surg Engl 1994;76:418-9.

22. Alvarado A. A practical score for the early diagnosis of acute appendicitis. Ann Emerg Med 1986;15:557-64. [CrossRef]

23. Dumlu EG, Tokaç M, Bozkurt B, Yildirim MB, Ergin M, Yalçin A, et al. Correlation between the serum and tissue levels of oxidative stress markers and the extent of inflammation in acute appendicitis. Clinics (Sao Paulo) 2014;69:677-82. [CrossRef] 


\section{ORİJINAL ÇALIŞMA - ÖZET}

\section{İskemi modifiye albümin ve diğer enflamatuvar belirteçlerin çocuk apandisit tanısındaki yeri}

\section{Dr. Selçuk Nazik, ${ }^{1}$ Dr. Veli Avci, ${ }^{2}$ Dr. Zeynep Küskü Kiraz ${ }^{3}$}

${ }^{1}$ Bingöl Kadın Doğum ve Çocuk Hastanesi, Enfeksiyon Hastalıkları ve Klinik Mikrobiyoloji Kliniği, Bingöl

Bingöl Kadın Doğum ve Çocuk Hastanesi, Çocuk Cerrahi Kliniği, Bingöl

${ }^{3}$ Osmangazi Üniversitesi Tıp Fakültesi, Biyokimya Anabilim Dalı, Eskişehir

AMAÇ: Bu çalışmada çocuklardaki apandisit ile iskemi modifiye albümin (IMA), C-reaktif protein (CRP), eritrosit sedimentasyon hızı (ESR), beyaz küre sayısı (WBC), nötrofil lenfosit oranı (NLR), platelet lenfosit oranı (PLR) ve ortalama platelet hacmi (MPV) arasındaki ilişkinin ortaya konulması amaçlandı.

GEREÇ VE YÖNTEM: Çalışmaya Mayıs 2015 ve Kasım 2015 tarihleri arasında hastanemize başvuran toplam 63 olgu dahil edildi, bunların 30 'u apandisit olgusu ve 33'ü sağlıklı kontrol olgu idi. Gruplar yaş ve cinsiyet açısından benzerdi.

BULGULAR: Apandisitli hastalarda IMA, CRP, ESR, WBC, MPV, NLR ve PLR değerlerinin ölçüldüğü ROC eğrisinin değerlendirilmesinde, en yüksek eğri altında kalan alan (EAA) IMA'da (EAA: 0.99I) tespit edilirken, onu takip eden EAA değerleri NLR (EAA: 0.946), CRP (EAA: 0.808), PLR (EAA: 0.779), ESR (EAA: 0.767), WBC (EAA: 0.749) ve MPV (EAA: 0.583) idi.

TARTIŞMA: Bu amaçla apandisit tanısında sıkça kullanılan yüksek WBC ve CRP düzeyi, sağ alt kadran ağrısı ve USG sonuçlarına ek olarak NLR, PLR, IMA ve ESR değerlerinin de tanıda kullanılmasının faydalı olacağı kanaatindeyiz.

Anahtar sözcükler: Apandisit; enflamatuvar belirteçler; iMA.

Ulus Travma Acil Cerrahi Derg 2017;23(4):317-321 doi: 10.5505/tjtes.2016.1 I823 